\title{
Unexpected Impact of COVID-19 Lockdown on the Air Quality in the Metro Atlanta, USA Using Ground-based and Satellite Observations
}

\author{
Guanyu Huang ${ }^{1 *}$, Reyla Ponder ${ }^{2,3}$, Amber Bond ${ }^{1}$, Hailey Brim ${ }^{1 \neq}$, Akua Temeng ${ }^{4}$, \\ Aaron R. Naeger ${ }^{5}$, Lei Zhu ${ }^{6}$ \\ ${ }^{1}$ Environmental and Health Sciences Program, Spelman College, Atlanta, GA 30314, USA \\ ${ }^{2}$ Department of Mathematics, Spelman College, Atlanta, GA 30314, USA \\ ${ }^{3}$ College of Civil and Environmental Engineering, Georgia Institute of Technology, Atlanta, GA \\ 30332, USA \\ ${ }^{4}$ Department of Chemistry and Biochemistry, Spelman College, Atlanta, GA 30314, USA \\ ${ }^{5}$ Earth System Science Center, University of Alabama in Huntsville, Huntsville, AL 35805, USA \\ ${ }^{6}$ School of Environmental Science and Engineering, Southern University of Science and \\ Technology, Shenzhen 518055, China
}

\section{ABSTRACT}

We studied the impact of COVID-19 (coronavirus disease 2019) lockdown on the air quality over the Atlanta area using satellite and ground-based observations, meteorological reanalysis data and traffic information. Unlike other cities, we found the air quality has improved slightly over the Atlanta area during the 2020 COVID-19 lockdown period (March 14-April 30, 2020), compared to the analogous period of 2019 (March 14-April 30, 2019). Ground $\mathrm{NO}_{2}$ concentrations have decreased slightly $10.8 \%$ and $8.2 \%$ over the near-road (NR) and urban ambient (UA) stations, respectively. Tropospheric $\mathrm{NO}_{2}$ columns have reduced $13 \%-49 \%$ over the Atlanta area from space-borne observations of TROPOspheric Monitoring Instrument (TROPOMI). Ground ozone and $\mathrm{PM}_{2.5}$ have decreased $15.7 \%$ and $\sim 5 \%$, respectively. This slight air quality improvement is primarily caused by the reduced human activities, as COVID-19 lockdowns have reduced $\sim 50 \%$ human activities, measured by traffic volume. Higher wind speed and precipitations also make the meteorological conditions favorable to this slight air quality improvement. We have not found a significant improvement in air quality over Atlanta amid the lockdown when human activities have reduced $\sim 50 \%$. Further studies are needed to understand the impacts of reduced human activities on atmospheric chemistry. We also found TROPOMI and ground measurements have disagreements on $\mathrm{NO}_{2}$ reductions, as collocated TROPOMI observations revealed $\sim 23 \%$ and $\sim 21 \%$ reductions of tropospheric $\mathrm{NO}_{2}$ columns over $\mathrm{NR}$ and UA stations, respectively. Several factors may explain this disagreement: First, tropospheric $\mathrm{NO}_{2}$ columns and ground $\mathrm{NO}_{2}$ concentrations are not necessarily the same, although they are highly correlated in the afternoon; Second, meteorological conditions may have different impacts on TROPMI and ground measurements. Third, TROPOMI may underestimate tropospheric $\mathrm{NO}_{2}$ due to uncertainties from air mass factors. Fourth, the uncertainties of chemiluminescence $\mathrm{NO}_{2}$ measurements used by ground stations. Consequently, studies using space-borne tropospheric $\mathrm{NO}_{2}$ column and ground $\mathrm{NO}_{2}$ measurements should take these factors into account.

Keywords: COVID-19, Air quality, TROPOMI, $\mathrm{NO}_{2}$

\section{INTRODUCTION}

As the outbreak of COVID-19 (coronavirus disease 2019) and its pandemic spread worldwide, many countries have implemented measures to slow down and prevent the spread of COVID-19. 
These COVID-19 lockdowns have caused significant reductions in human activities and traffic worldwide. As human activities have reduced, air quality has improved significantly worldwide (Bauwens et al., 2020; Goldberg et al., 2020; Huang and Sun, 2020; Jin et al., 2020; Koo et al., 2020; Liu et al., 2020; Morales-Solís et al., 2021; Naeger and Murphy, 2020; Oo et al., 2021; Represa et al., 2021). However, some studies found air quality has not improved as we expected or even worsened in some cities due to the complicated atmospheric chemistry, meteorological conditions, and emissions, even anthropogenic emissions from human activities and traffic have reduced significantly (Bekbulat et al., 2021; Chen et al., 2020; Le et al., 2020; Schiermeier, 2020; Shi and Brasseur, 2020).

The variation of ground air pollutants is controlled by complicated and non-linear physical and chemical processes (Kroll et al., 2020; Seinfeld and Pandis, 2016). Nitrogen oxides $\left(\mathrm{NO}_{\mathrm{x}}=\mathrm{NO}+\mathrm{NO}_{2}\right.$ ) emitted into the atmosphere from anthropogenic sources are a major driver of ambient $\mathrm{NO}_{2}$ concentrations over populous areas in the world (Lamsal et al., 2013, 2008). It is not surprising that ambient $\mathrm{NO}_{2}$ has reduced significantly in many areas due to the reduced human activities by COVID-19 lockdowns (Huang and Sun, 2020; Liu et al., 2020; Naeger and Murphy, 2020). The chemistry of ozone and aerosols (e.g., Particulate Matter $2.5\left(\mathrm{PM}_{2.5}\right)$ ) are more complicated than $\mathrm{NO}_{2}$. The production of ozone depends on volatile organic compounds (VOCs) and $\mathrm{NO}_{x}$ with the presence of sunlight. When VOCs are high and $\mathrm{NO}_{\mathrm{x}}$ is low, it is the "NO${ }_{x}$ " controlled situation. In this situation, more $\mathrm{NO}_{\mathrm{x}}$ means more ozone. When VOCs are low and $\mathrm{NO}_{\mathrm{x}}$ is high, it is the "VOCs" limited situation. More $\mathrm{NO}_{\mathrm{x}}$ does not produce more ozone or even decrease ozone (Kroll et al., 2020). The chemistry of $\mathrm{PM}_{2.5}$ is even more complicated. $\mathrm{PM}_{2.5}$ can be emitted directly from combustion and produced through gas-phase chemical reactions to form products of low enough volatility to condense into the particle phase. In addition, secondary organic aerosols (SOAs) makes it even more complicated (Kroll et al., 2020; Seinfeld and Pandis, 2016). As a result, ozone and $\mathrm{PM}_{2.5}$ have had more diverse responses during the COVID-19 lockdowns (Bekbulat et al., 2021; Chen et al., 2020). Many studies have shown ozone increased, whereas $P_{2.5}$ decreased slightly, as the increase of government stringency (Gkatzelis et al., 2021). However, cities with slightly better or even worse air quality during COVID-19 lockdowns may need further analysis due to their unexpected responses to reduced human activities. COVID-19 lockdowns provide us a special scenario to understand the mechanisms that controlling air quality under reduced human activities (Kroll et al., 2020). In addition, analysis on meteorology is essential to interpretate the relationship between COVID-19 lockdowns and air quality (Goldberg et al., 2020). Unfortunately, many previous studies had not taken metrological conditions into account (Gkatzelis et al., 2021).

Atlanta is the largest and most populous metropolitan area in the southeastern United States. People's activities heavily depend on private vehicles, as traffic information is a good indicator of human activities. Geographically, Atlanta is an isolated non-attainment area and its major source of air pollutants are from local emissions (Diem, 2009). As one of the most diverse major cities in the U.S., Atlanta has been suffering air quality disparities and environmental justice for a long time (Park and Kwan, 2020; Servadio et al., 2019). These environmental justice issues have worsened worldwide during the COVID-19 pandemic (Kerr et al., 2021). Consequently, it is essential to analyze the impact of COVID-19 lockdown on the air quality in the Atlanta area for the local air quality management and environmental justice. Unfortunately, no previous studies have done such analysis in the Atlanta area.

This study aims to assess the impact of COVID-19 lockdown on the air quality in the Atlanta metropolitan using measurements of $\mathrm{NO}_{2}$, ozone and $\mathrm{PM}_{2.5}$ from multiple ground stations and spacebased tropospheric $\mathrm{NO}_{2}$ observations in conjunction with meteorological and traffic information.

\section{STUDY AREA, DATA AND MATERIALS}

\subsection{Study Areas and COVID-19 Control Measures in Atlanta}

The Atlanta metropolitan area in the state of Georgia is one of the major metropolitans in the United States that experience high concentrations of air pollution due to a range of factors, including urbanization and anthropogenic emissions (Diem, 2009; Henneman et al., 2015, 2017). Most population of Atlanta concentrates in the area inside of Interstate Loop Highway (I-285) including the City of Atlanta, other cities, and unincorporated areas. In this study, we focus on 
the highly urbanized and populous area inside of Interstate Highway 285 (I-285) loop as shown in Fig. 1.

The state of Georgia declared a Public Health State of Emergency in response to COVID-19 on March 14, 2020 (The State of Georgia, 2020a), a shelter-in-place order on March 23, 2020 in order to slow the spread of COVID-19, lifted the order on April 30,2020 (The State of Georgia, 2020b). The 2020 COVID-19 lockdown period and its analogous period of 2019 are defined March 14April 30, 2020 and March 14-April 30, 2019, respectively, in this study.

\subsection{Ground-based Air Quality Measurements}

We obtain our hourly measurements from ground stations operated and maintained by Georgia Environmental Protection Division, with monitor locations indicated in Fig. 1 (Georgia Department of Natural Resources, 2020). Hourly $\mathrm{NO}_{2}$ measurements are obtained from the South DeKalb, an urban ambient (UA) station, and NR-285, a near-road (NR) background station (Georgia Department of Natural Resources, 2020). Ground $\mathrm{NO}_{2}$ has been measured by U.S. Environmental Protection Agency (U.S. EPA)-designated $\mathrm{NO}_{2}$ chemiluminescence automated Federal Reference Method (FRM) (Georgia Department of Natural Resources, 2020). The South DeKalb and NR-285 stations both use Thermo Scientific Model 42i ( $\mathrm{NO}-\mathrm{NO}_{2}-\mathrm{NO}_{\mathrm{x}}$ ) Analyzer for $\mathrm{NO}_{2}$ monitoring with 0-0.05 to 100 ppm range and \pm 0.40 ppb precision (Georgia Department of Natural Resources, 2020). These regulatory $\mathrm{NO}_{2}$ chemiluminescence measurements are known to contain some uncertainties due to their sensitivity to other nitrogen species (Dunlea et al., 2007). The magnitude

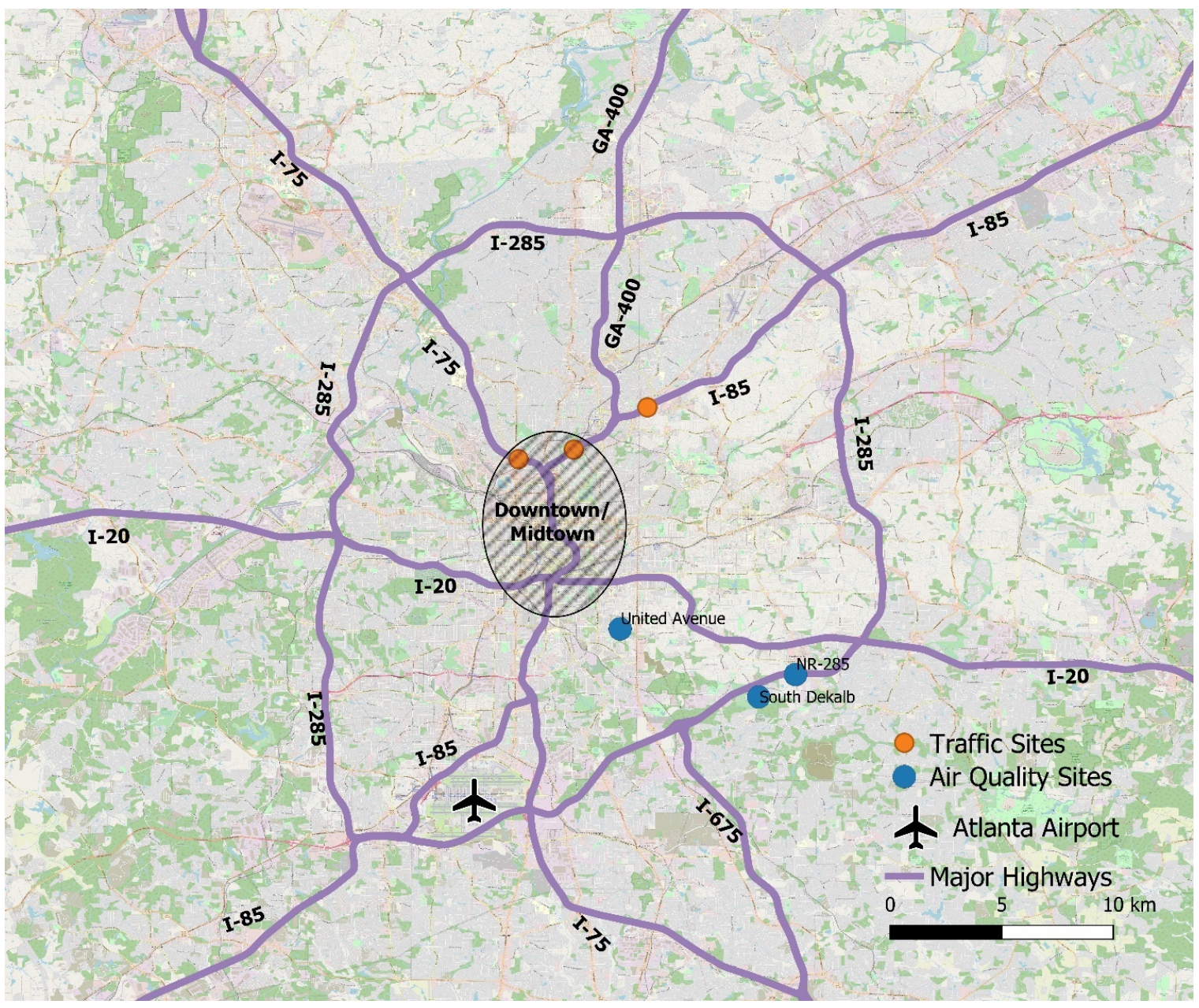

Fig. 1. Map of the Atlanta metropolitan area. The purple lines represent major highways, including interstate highways (e.g., I-75, I-85, I-285 and I-675) and Georgia 400 highway (marked as GA-400). Orange and blue dots represent traffic volume measurement sites and air quality measurements sites, respectively. The airplane symbol represents the Atlanta International Airport. The shadow area shows the downtown and midtown areas of Atlanta. 
of the total interference is variable, and depends not only on the relative fraction of actual $\mathrm{NO}_{2}$ to total reactive nitrogen compounds $\left(\mathrm{NO}_{\mathrm{y}}\right)$, but also on the characteristics of individual monitors (Lamsal et al., 2015). Consequently, ground $\mathrm{NO}_{2}$ measurements may overestimate $\mathrm{NO}_{2}$ concentrations, with minimum biases in the morning and maximum biases in the early afternoon, close to the overpass time of TROPOMI (Dunlea et al., 2007; Lamsal et al., 2015).

Hourly $\mathrm{PM}_{2.5}$ and ozone measurements are obtained from South DeKalb and United Avenue stations, both urban UA stations. The hourly data at South DeKalb station are from a Teledyne T640 PM Mass Monitor which an optical aerosol spectrometer for measurement with 0.1-10000 $\mathrm{g} \mathrm{m}^{-3}$ measurement range and $0.5 \mu \mathrm{g} \mathrm{m}^{-3}$ (1-h average) (Georgia Department of Natural Resources, 2019). The United Avenue station uses a tapered element oscillating microbalance (TEOM) which collects particles on a filter with a measurement range of $0-5 \mathrm{~g} \mathrm{~m}^{-3}$, and $1.5 \mu \mathrm{g} \mathrm{m}^{-3}$ precision (1hour average) (Georgia Department of Natural Resources, 2020). The hourly ozone measurements of both stations are obtained from Model 49i Ozone Analyzer manufactured by Thermo Fisher that is based on continuous ultraviolet photometric method. The measurement range is from 0.05 ppb to 200 ppm with 1.0 ppb precision (Georgia Department of Natural Resources, 2020).

\subsection{Meteorological Data}

We use meteorological data from MERRA-2 (Modern-Era Retrospective analysis for Research and Applications, Version 2) (Gelaro et al., 2017). These meteorological data include 2-meter (2 m) wind speed, $2 \mathrm{~m}$ wind direction, $2 \mathrm{~m}$ temperature and $2 \mathrm{~m}$ relative humidity (RH), $850 \mathrm{hPa}$ and $500 \mathrm{hPa}$ wind speed and wind direction, planetary boundary layer (PBL) top pressure and cloud cover. MERRA-2 is an atmospheric reanalysis model produced by NASA Global Modeling and Assimilation Office (GMAO) with a spatial resolution of $0.5^{\circ} \times 0.625^{\circ}$. Due to the spatial resolution of our meteorological data, microscale and fine mesoscale features will not be accounted for, but these effects should be minor in this study. In addition, we obtain precipitation measurements from the weather station located in Atlanta Hartsfield Jackson International Airport as shown in Fig. 1.

\subsection{TROPOMI $\mathrm{NO}_{2}$ Observations}

TROPOMI is the single payload aboard the Sentinel 5 Precursor (S5P) satellite that has a sunsynchronous orbit with a local overpass time of approximately 13:30 with a near-daily global coverage since April 2018 (Veefkind et al., 2012). The TROPOMI NO 2 retrieval algorithm is developed by the Royal Netherlands Meteorological Institute and based on the $\mathrm{NO}_{2}$ DOMINO algorithm with significant improvements including the improved retrieval of slant column density and spectral fitting (Boersma et al., 2018; Lorente et al., 2017; Van Geffen et al., 2015). TROPOMI retrieves tropospheric $\mathrm{NO}_{2}$ with a pixel size of $7 \mathrm{~km} \times 3.5 \mathrm{~km}$ at nadir, and the resolution has been improved to $5.5 \mathrm{~km} \times 3.5 \mathrm{~km}$ with a change in the S5P operation scenario since August 6, 2019 (orbit 9388) (Eskes and Eichmann, 2019). We only use TROPOMI offline observations with cloud coverage less than 0.3 , and quality assurance greater than 0.75 (Eskes and Eichmann, 2019).

\subsection{Traffic Data}

We use traffic count data as the indicator of human activities in this study, as private vehicles are the major commuting tool in the Atlanta area (Atlanta Regional Commision, 2020). The traffic count data are collected from the Georgia Department of Transportation (GDOT) using the (GDOT)'s Traffic Analysis and Data Application (TADA) (https://gdottrafficdata.drakewell.com/pu blicmultinodemap.asp). GDOT collects traffic information through Continuous Count Stations (CCSs) installed on all types of public roads in Georgia. Each CCS is designed to provide volume counts continuously (24 hours per day, 7 days per week, 365 days per year) except during maintenance periods. We select three CCSs on major highways in the downtown and midtown areas of Atlanta to capture the traffic variation during the COVID-19 lockdown as shown in Fig. 1.

\section{METHODOLOGY}

\subsection{Conversion of TROPOMI Level 2 Data to Level 3}

We produce level 3 data in the 2020 COVID-19 lockdown period (March 14-April 30, 2020) and its analogous period of 2019 (March 14-April 30, 2019) by averaging level 2 data to a common, 
regular $0.01^{\circ} \times 0.01^{\circ}$ grid and using a physical oversampling method to the regridded level 3 tropospheric $\mathrm{NO}_{2}$ data. The physical oversampling method by Sun et al. (2018) temporally and spatially averages the level 2 satellite observations to level 3 grids. Two-dimensional super Gaussian functions are used to represent the spatial response functions of satellite sensors. In comparison with conventional approaches that only consider the pixel corners, this method gives considerable advantages of visualizing the distribution and local gradients of trace gases and for scenarios with short temporal windows (Huang and Sun, 2020; Sun et al., 2018).

\section{RESULTS AND DISCUSSION}

\subsection{Meteorological Analysis}

We compare meteorological parameters over the Atlanta area during the 2020 COVID-19 lockdown period and its analogous period in 2019 as listed in Table 1 . The $2 \mathrm{~m}$ wind are similar in $2019\left(1.12 \pm 0.53 \mathrm{~m} \mathrm{~s}^{-1}\right)$ and $2020\left(1.09 \pm 0.50 \mathrm{~m} \mathrm{~s}^{-1}\right)$ with wind direction changing from southwesterly $\left(233^{\circ} \pm 91^{\circ}\right)$ in 2019 to westerly $\left(273^{\circ} \pm 83^{\circ}\right)$ in $2020.850 \mathrm{hPa}$ and $500 \mathrm{hPa}$ winds have also increased $16 \%$ from $8.53 \mathrm{~m} \mathrm{~s}^{-1}\left( \pm 4.61 \mathrm{~m} \mathrm{~s}^{-1}\right)$ in 2019 to $9.92 \mathrm{~m} \mathrm{~s}^{-1}\left( \pm 4.29 \mathrm{~m} \mathrm{~s}^{-1}\right)$ in 2020, and $44 \%$ from $17.89 \mathrm{~m} \mathrm{~s}^{-1}\left(\left( \pm 7.53 \mathrm{~m} \mathrm{~s}^{-1}\right)\right.$ in 2019 to $25.72 \mathrm{~m} \mathrm{~s}^{-1}\left( \pm 7.04 \mathrm{~m} \mathrm{~s}^{-1}\right)$ in 2020, respectively. The wind direction at $850 \mathrm{hPa}$ has changed from $247^{\circ}\left( \pm 74^{\circ}\right)$ in 2019 to $264^{\circ}\left( \pm 41^{\circ}\right)$ in 2020, while the wind direction at $500 \mathrm{hPa}$ has changed slightly from $266^{\circ}\left( \pm 32^{\circ}\right)$ in 2019 to $270^{\circ}\left( \pm 19^{\circ}\right)$ in 2020 .

The wind speed enhancement and wind direction change in 2020 may have strong and different impacts on the air pollution at ground level. 2-m wind direction has changed from $233^{\circ}$ in 2019 to $273^{\circ}$ in 2020 , while the wind speed is similar. The dominant west wind in 2020 may transport air pollutants from downtown and midtown areas to the west of Atlanta, where all ground stations are, to increase ground stations' measurements. The impact of wind direction change may have a larger impact on the NR station. The dominant southwest wind at $2 \mathrm{~m}$ height in 2019 blows air pollutants away from the NR-285 station located in the south of I-285, while the dominant west wind in 2020 increases the concentrations at NR-285 station (Richmond-Bryant et al., 2017; Venkatram et al., 2013). As a result, the wind direction change may reduce the $\mathrm{NO}_{2}$ difference between 2020 and 2019 measured by both ground stations.

The higher wind speed at $850 \mathrm{hPa}$ in 2020 may improve air quality through rapid transport and dispersion of air pollutants from local emission sources, even 2-m wind speed are similar in 2019 and 2020 (Goldberg et al., 2020; Naeger and Murphy, 2020). The larger enhancement of wind speed at $500 \mathrm{hPa}$ in 2020 may cause more reductions in tropospheric $\mathrm{NO}_{2}$ columns observed by TROPOMI than ground $\mathrm{NO}_{2}$ measurements.

Temperature in 2020 COVID-19 lockdown period is slightly higher than the analogous period of 2019, while relative humidity, atmospheric boundary layer heights and cloud cover are similar in 2019 and 2020. On the other hand, the precipitation in 2020 is $28 \%$ higher than 2019. The considerably larger precipitation in 2020 is expected to washout air pollutants to improve the air quality in 2020 (Goldberg et al., 2020). In sum, meteorological conditions have contributed to improved air quality in the Atlanta area in the 2020 COVID-19 lockdown period. The meteorological conditions have different impacts on concentrations of air pollutants measured by ground stations and satellites.

\subsection{Traffic Volume}

Traffic volume has reduced $48.7 \%$ in 2020 relative to 2019 in the downtown and midtown areas of Atlanta due to the COVID-19 lockdown. Fig. 2(a) shows the mean hourly traffic volume

Table 1. Mean meteorological fields with standard deviations over the Atlanta area during the COVID-19 lockdown period in 2020 and the analogous period in 2019.

\begin{tabular}{|c|c|c|c|c|c|c|c|c|c|c|}
\hline $\begin{array}{l}2 \mathrm{~m} \mathrm{WS}^{-1} \\
\left(\mathrm{~m} \mathrm{~s}^{-1}\right)\end{array}$ & $\begin{array}{l}2 \mathrm{~m} \text { WD } \\
\left({ }^{\circ}\right)\end{array}$ & $\begin{array}{l}850 \mathrm{hPa} \\
\mathrm{WS}\left(\mathrm{m} \mathrm{s}^{-1}\right)\end{array}$ & $\begin{array}{l}850 \mathrm{hPa} \\
\mathrm{WD}\left({ }^{\circ}\right)\end{array}$ & $\begin{array}{l}500 \mathrm{hPa} \\
\mathrm{WS}\left(\mathrm{m} \mathrm{s}^{-1}\right)\end{array}$ & $\begin{array}{l}500 \mathrm{hPa} \\
W D\left({ }^{\circ}\right)\end{array}$ & $\begin{array}{l}\text { Temp. } \\
\left({ }^{\circ} \mathrm{C}\right)\end{array}$ & $\begin{array}{l}\text { PBL Top } \\
\text { (hPa) }\end{array}$ & $\begin{array}{l}\mathrm{Rh} \\
\text { (\%) }\end{array}$ & $\begin{array}{l}\text { Cloud } \\
\text { Cover }\end{array}$ & $\begin{array}{l}\text { Prep. } \\
\text { (mm) }\end{array}$ \\
\hline
\end{tabular}

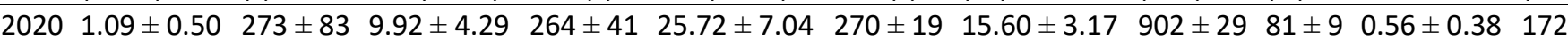

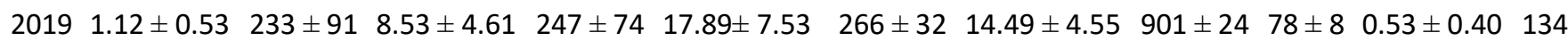


from February 1 to April 30 in both 2019 and 2020. We have applied a 7-day moving average to smooth out the weekend's effect on traffic volume. The traffic volume does not have a strong variation in 2019 and the traffic volume before the lockdown in 2020 is similar to 2019. The traffic volume has decreased dramatically as the declaration of public health emergency on March 14, 2020 , and reached the minimum on April 7, 2020, approximately $60 \%$ less than in the same period of 2019.

The daily variation of hourly traffic volume in the COVID-19 lockdown of 2020 and its analogous period of 2019 are shown in Figs. 2(b) and 2(c). Atlanta has long peak traffic hours from 6:0019:00 daily in 2019. These hourly traffic features in the 2020 COVID-19 lockdown are similar to 2019 with significant reductions. The traffic volume in 2020 has reduced $40 \%-50 \%$ during peak hours (6:00-19:00), and 50\%-63\% during off-peak hours (20:00-5:00).
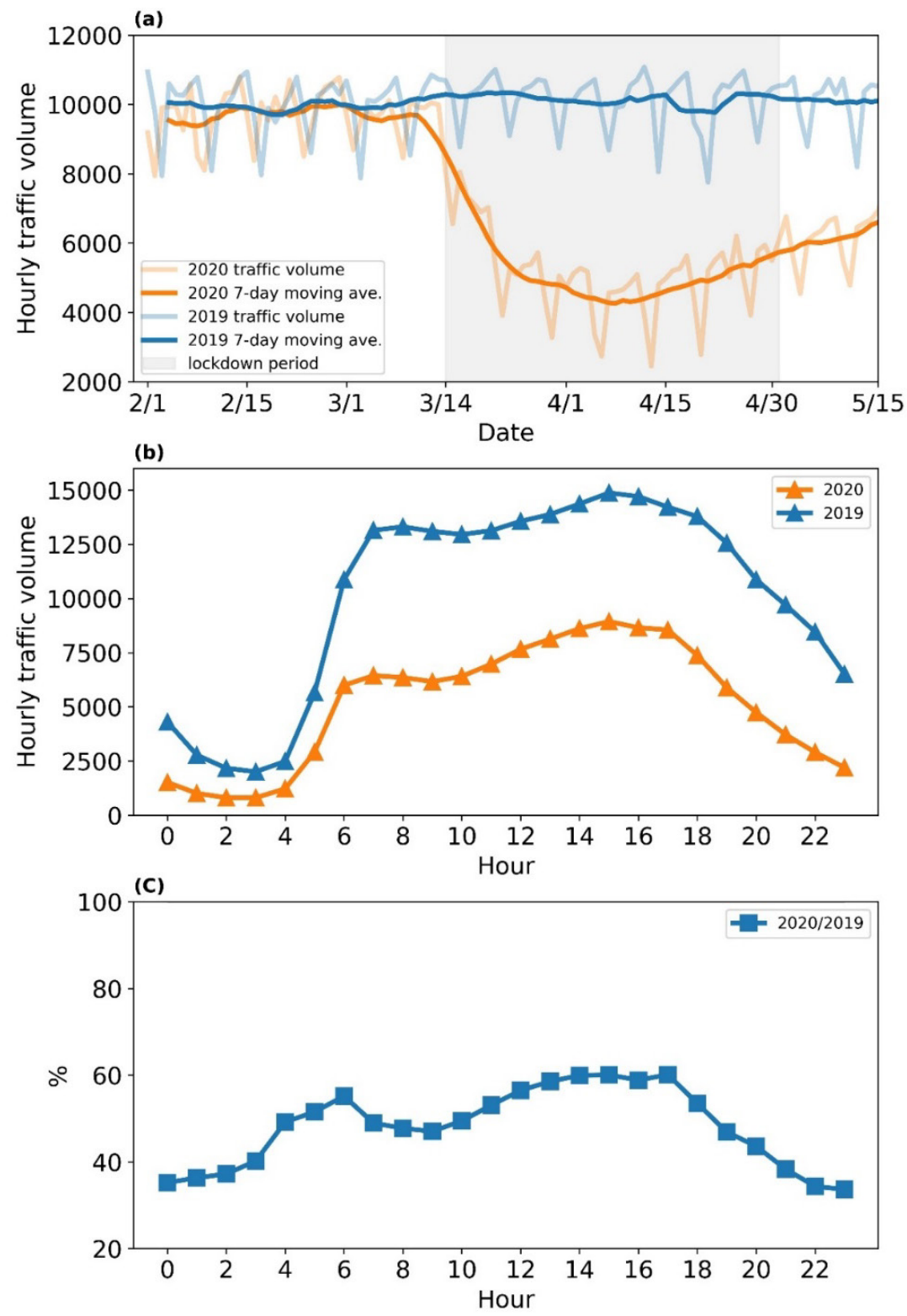

Fig. 2. Hourly traffic volume in the Atlanta area. Panel (a) plots time series of hourly traffic volume in 2019 (marked in light blue) and 2020 (marked in light orange), and 7-day moving average hourly traffic volume in 2019 by solid blue lines and 2020 by solid orange lines. Panel (b) plots hourly mean traffic volume during COVID-19 lockdown in 2020 marked by solid orange lines and the analogous period in 2019 marked by solid blue lines, respectively. Panel (c) plots ratios of hourly traffic of 2020 COVID-19 lockdown to the 2019 analogous period. 


\section{$4.3 \mathrm{NO}_{2}$}

Tropospheric $\mathrm{NO}_{2}$ columns from TROPOMI in 2020 COVID-19 lockdown and the analogous period in 2019 are shown in Figs. 3(a) and 3(b). Tropospheric $\mathrm{NO}_{2}$ columns have remained high ( $>0.1$ Dobson Unit (DU)) over the entire Atlanta area in 2019, with tropospheric $\mathrm{NO}_{2}$ hotspots along major highways, over the downtown and midtown of Atlanta ( $0.15 \mathrm{DU})$, and Atlanta International Airport ( $>0.15 \mathrm{DU}$ ) as shown in Fig. 3(a). These tropospheric $\mathrm{NO}_{2}$ hotspots in downtown and midtown areas are associated with human activities and ground traffic; the hotspot near Atlanta International Airport is associate with air traffic (Rissman et al., 2013).

During the COVID-19 lockdown, tropospheric $\mathrm{NO}_{2}$ columns have reduced $28.1 \%(0.03 \mathrm{DU})$ over the entire Atlanta metropolitan area as shown in Fig. 3(c). However, some tropospheric $\mathrm{NO}_{2}$ hotspots with fewer intensities still exist in 2020 in junctions of major highways located in the northwest, northeast and southwest corners of I-285 likely due to the remaining traffic. Goldberg et al. (2020) has shown a $35.2 \%$ reduction of tropospheric $\mathrm{NO}_{2}$ columns over the Atlanta area in 2020 lockdown period, compared to the analogous period of 2019. Our results are comparable with this study.

Mean ground $\mathrm{NO}_{2}$ measurements in 2020 COVID-19 lockdown and the analogous period of 2019 are listed in Table 2. Ground $\mathrm{NO}_{2}$ measurements have also decreased in 2020 COVID-19 lockdown period. $\mathrm{NR} \mathrm{NO}_{2}$ has decreased from $14.99 \mathrm{ppb}( \pm 5.67 \mathrm{ppb})$ in 2019 to $13.37 \mathrm{ppb}( \pm 4.42$ $\mathrm{ppb})$ in 2020 with $10.8 \%$ reduction. $\mathrm{UA} \mathrm{NO}_{2}$ has decreased from $8.25 \mathrm{ppb}( \pm 3.23 \mathrm{ppb})$ in 2019 to $7.57 \mathrm{ppb}( \pm 3.02 \mathrm{ppb})$ in 2020 with $8.2 \%$ reduction.

Fig. 4 plots the hourly variation of $\mathrm{NO}_{2}$ in 2020 COVID-19 lockdown and the analogous period of 2019. Although daily mean $\mathrm{NO}_{2}$ has decreased in 2020, hourly mean $\mathrm{NO}_{2}$ in 2020 are not consistently lower than 2019 as shown in Fig. 4(a). $2020 \mathrm{NR} \mathrm{NO}_{2}$ during 19:00 and 8:00 is up to $\sim 25 \%$ lower than $2019 \mathrm{NR} \mathrm{NO}_{2}$ at the same hours, while $2020 \mathrm{NR} \mathrm{NO}_{2}$ during 11:00 and 18:00 is up to $35 \%$ higher than 2019. On the other hand, $\mathrm{UA} \mathrm{NO}_{2}$ in 2020 is $10 \%$ higher than 2019 during 22:00 to 1:00, while $2020 \mathrm{UA} \mathrm{NO}_{2}$ become up to $30 \%$ lower than 2019 from 3:00 to 10:00. UA $\mathrm{NO}_{2}$ from 11:00 to 20:00 in 2020 is slightly less than 2019.

(a) 2019

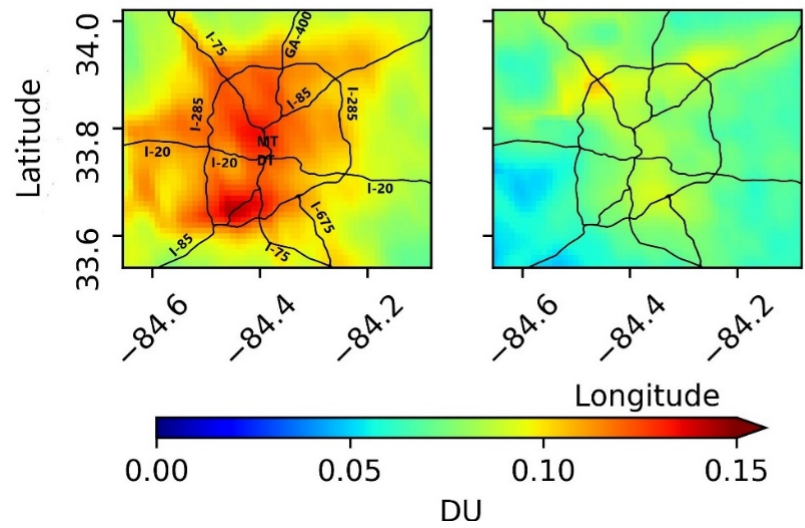

(c) $2020-2019$

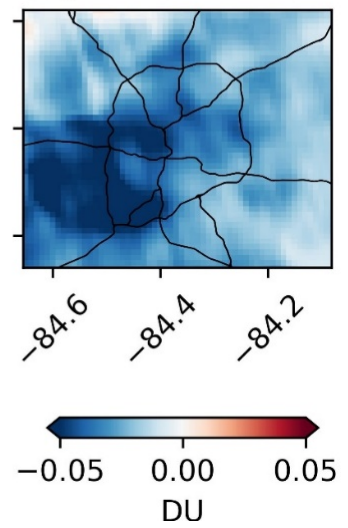

Fig. 3. Tropospheric $\mathrm{NO}_{2}$ column densities over the Atlanta area observed by TROPOMI during the 2020 COVID-19 lockdown (March 14-April 30, 2020) in panel (a) and the 2019 analogous period (March 14-April 30, 2019) in panel (b). MT and DT represents the midtown and downtown areas of Atlanta. Panel (c) plots the differences of tropospheric $\mathrm{NO}_{2}$ columns over the Atlanta area in 2020 COVID-19 lockdown and 2019 analogous period (2020 minus 2019).

Table 2. Mean and standard deviation of $\mathrm{NO}_{2}$ (near-road (NR) and background (UA)), ozone and $\mathrm{PM}_{2.5}$ concentrations during the COVID-19 lockdown period 2020 and the analogous period of 2019.

\begin{tabular}{lllll}
\hline & \multicolumn{2}{c}{$\mathrm{NO}_{2}(\mathrm{ppb})$} & \multirow{2}{*}{ Ozone $(\mathrm{ppb})$} & \multirow{2}{*}{$\mathrm{PM}_{2.5}\left(\mu \mathrm{m} \mathrm{m}^{-3}\right)$} \\
\cline { 2 - 5 } & $\mathrm{NR}$ & $\mathrm{UA}$ & & \\
\hline 2020 & $13.37 \pm 4.24$ & $7.57 \pm 3.02$ & $28.40 \pm 8.94$ & $9.98 \pm 1.58$ \\
2019 & $14.99 \pm 5.67$ & $8.25 \pm 3.23$ & $33.67 \pm 9.78$ & $10.44 \pm 1.78$ \\
\hline
\end{tabular}



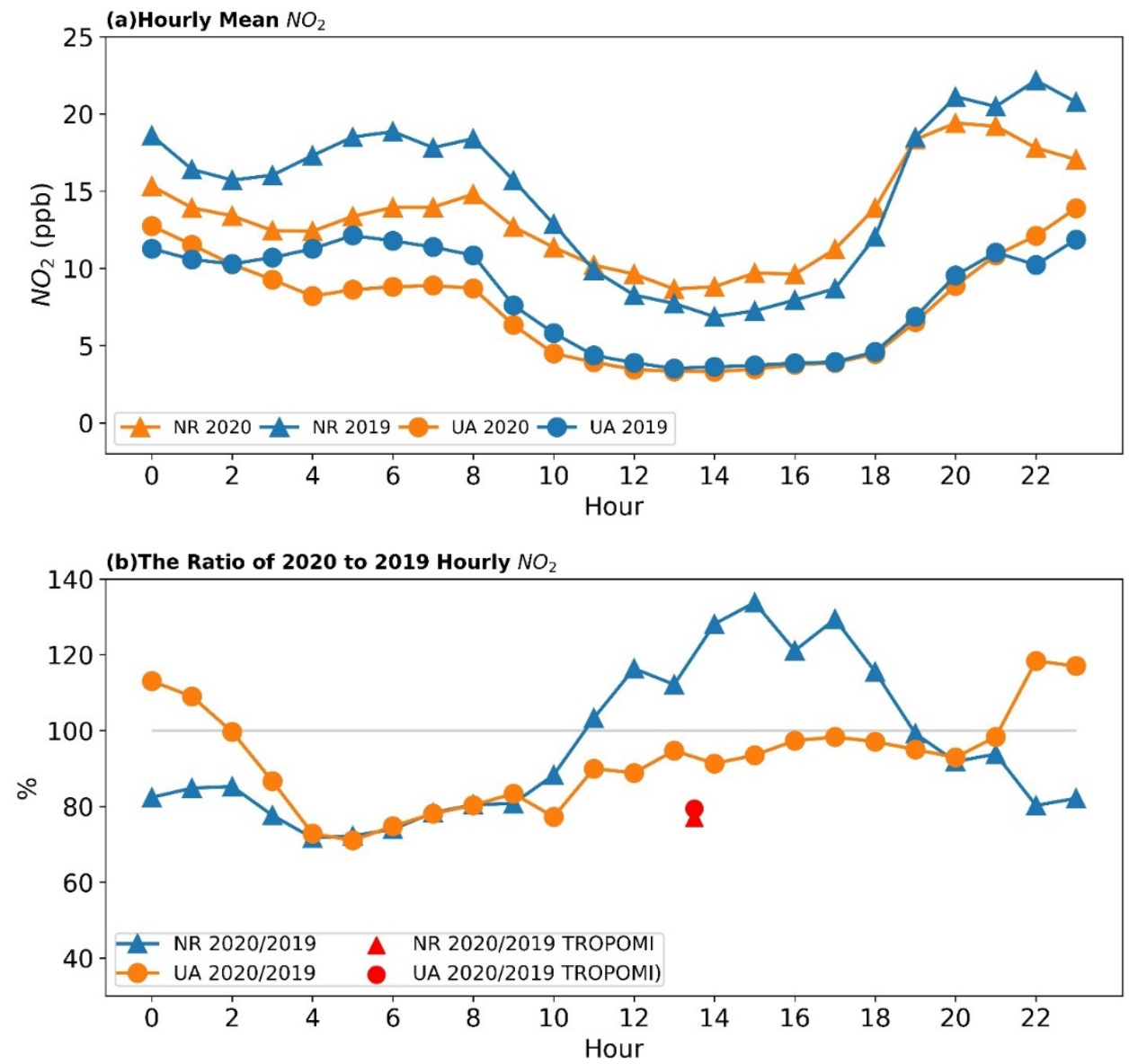

Fig. 4. Hourly mean $\mathrm{NO}_{2}$ measured by a near-road (NR, NR-285) station and urban ambient (UA, South Dekalb) station during 2020 COVID-19 lockdown period (March 14-April 30, 2020) and the analogous period of 2019 (March 14-April 30, 2019) in the Atlanta area. Panel (a) shows hourly mean $\mathrm{NO}_{2}$ in 2019 (marked by blue) and 2020 (marked by orange) measured by near-road (NR, marked by triangles) and background (UA, marked by rounds), respectively. Panel (b) plots ratios of hourly $2020 \mathrm{NO}_{2}$ to $2019 \mathrm{NO}_{2}$ measured by NR and UA ground stations marked by blue triangles and rounds, respectively. The red triangle and round represent ratios of 2020 to 2019 tropospheric $\mathrm{NO}_{2}$ columns measured by TROPOMI collocated with NR and UA ground stations, respectively.

Collocated TROPOMI observations have indicated more significant reductions of tropospheric $\mathrm{NO}_{2}$. These collocated tropospheric $\mathrm{NO}_{2}$ columns are mean values of tropospheric $\mathrm{NO}_{2}$ columns of $3 \times 3$ grids centered at each station. TROPOMI observations have shown tropospheric $\mathrm{NO}_{2}$ over NR and UA stations have decreased $\sim 23 \%$ and $21 \%$ at the overpass time of TROPOMI ( 13:30 local time), respectively. These reductions of tropospheric $\mathrm{NO}_{2}$ columns observed by TROPOMI are higher than the reductions observed by ground stations. There are several factors may cause this disagreement between TROPOMI and ground observations. First, the tropospheric $\mathrm{NO}_{2}$ columns measured by TROPOMI and $\mathrm{NO}_{2}$ measured by ground stations are not the same, although tropospheric $\mathrm{NO}_{2}$ columns and ground $\mathrm{NO}_{2}$ may have high correlations (Cersosimo et al., 2020; Demetillo et al., 2020). The reductions in traffic and human activities may cause different percentage reductions for ground $\mathrm{NO}_{2}$ and tropospheric $\mathrm{NO}_{2}$ columns. Second, meteorological conditions may have different impacts on TROPOMI and ground measurements as discussed in Section 4.1. Third, TROPOMI may underestimate tropospheric $\mathrm{NO}_{2}$ due to uncertainties from air mass factors (Griffin et al., 2019). Forth, the uncertainties of chemiluminescence $\mathrm{NO}_{2}$ measurement may also contribute to this disagreement as these uncertainties reach maximum in the early afternoon and minimum in the morning (Dunlea et al., 2007; Lamsal et al., 2015). Ground $\mathrm{NO}_{2}$ measurements in 4:00-8:00 show $\sim 18-30 \%$ reductions of $\mathrm{NO}_{2}$ in both NR and UA stations as shown in Fig. $4(\mathrm{~b})$. These $\mathrm{NO}_{2}$ reduction measured by ground stations agree well with TROPOMI 
observations. Consequently, studies using satellite and ground $\mathrm{NO}_{2}$ measurements should take these factors into account.

\subsection{Ozone}

Mean ground ozone mixing ratio during COVID-19 lockdowns in 2020 and its analogue periods of 2019 are listed in Table 2. Mean ground ozone during 2020 COVID-19 lockdowns has decreased $15.7 \%$ from $33.67 \mathrm{ppb}( \pm 9.78 \mathrm{ppb})$ to $28.40 \mathrm{ppb}( \pm 8.94 \mathrm{ppb})$ in the analogous period in 2019 .

Ground ozone during 2020 COVID-19 lockdowns has reduced consistently relevant to the analogous period in 2019 as shown in Fig. 5. Ground ozone has decreased 15-20\% during daytime, and $20-30 \%$ during nighttime. Ground ozone has indicated the smallest reductions as $5-10 \%$ during morning and evening transition time. The Atlanta area is a $\mathrm{NO}_{\mathbf{x}}$-controlled scenario for ozone production (Jin et al., 2020; McDonald et al., 2018; Wolff et al., 2013). The combination of slightly increased Formaldehyde ( $\mathrm{HCHO}$ ) (Sun et al., 2021) and reduced $\mathrm{NO}_{x}$ emissions have developed a more $\mathrm{NO}_{\mathrm{x}}$-controlled scenario for ozone production in the Atlanta area. As a result, this significant

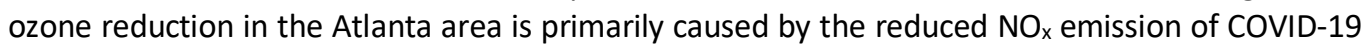
lockdowns and increased $\mathrm{HCHO}$ emission of high temperature.

\section{5 $\mathrm{PM}_{2.5}$}

Mean PM2.5 during 2020 COVID-19 lockdowns is $9.98 \mu \mathrm{g} \mathrm{m}^{-3}\left( \pm 1.58 \mu \mathrm{g} \mathrm{m}^{-3}\right)$, with $5 \%$ less than $10.44 \mu \mathrm{g} \mathrm{m}^{-3}\left( \pm 1.78 \mu \mathrm{g} \mathrm{m}^{-3}\right)$ in the analogous period in 2019 as listed in Table 2. Hourly mean $\mathrm{PM}_{2.5}$ concentrations during 2020 COVID-19 lockdown are slightly lower than the analogous period in 2019 at most time as shown in Fig. 6. PM2.5 in 2020 is up to $17 \%$ lower than 2019 most time but up to $\sim 8 \%$ higher during 13:00-16:00. The $\mathrm{PM}_{2.5}$ chemistry is more complicated than ozone.

(a) Houly Mean Ozone

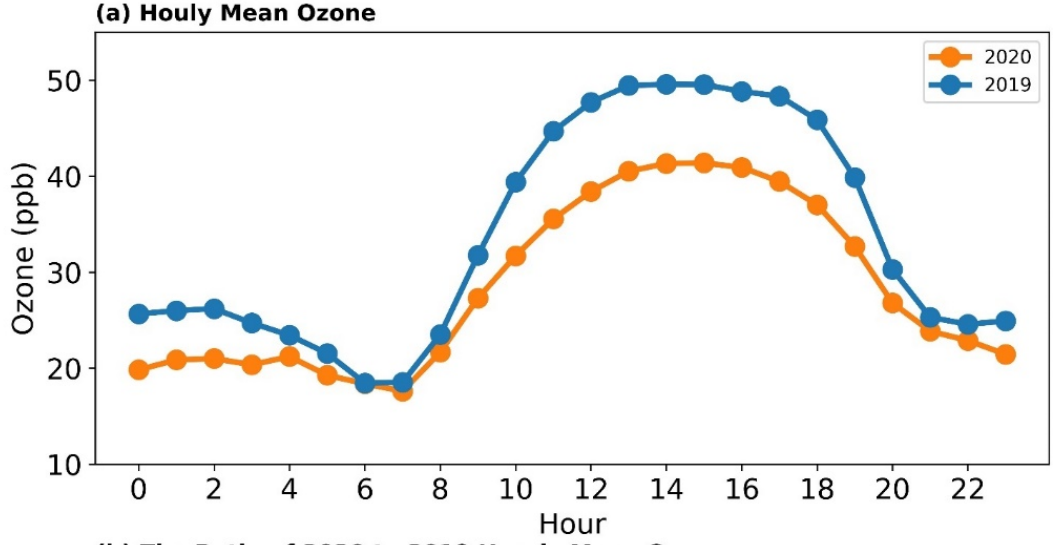

(b) The Ratio of 2020 to 2019 Hourly Mean Ozone

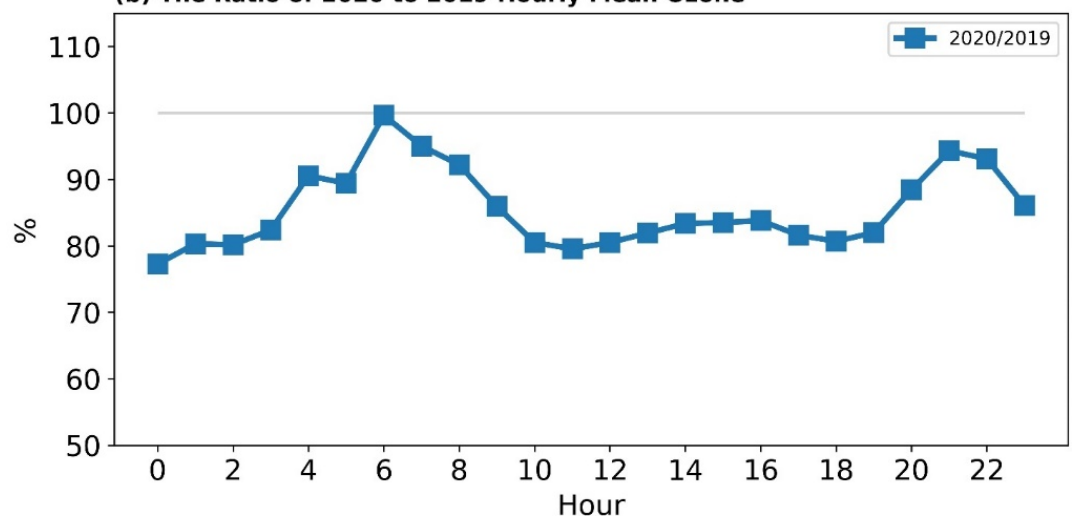

Fig. 5. Hourly mean ozone mixing ratio measured by urban ambient (UA) stations, South DeKalb and United Avenue during 2020 COVID-19 lockdown period (March 14-April 30, 2020) and the analogous period of 2019 (March 14-April 30, 2019). Panel (a) shows hourly mean ozone concentrations in 2019 (marked by blue) and 2020 (marked by orange), respectively. Panel (b) plots ratios of hourly 2020 ozone to 2019 ozone. 
(a) Hourly Mean PM2.5
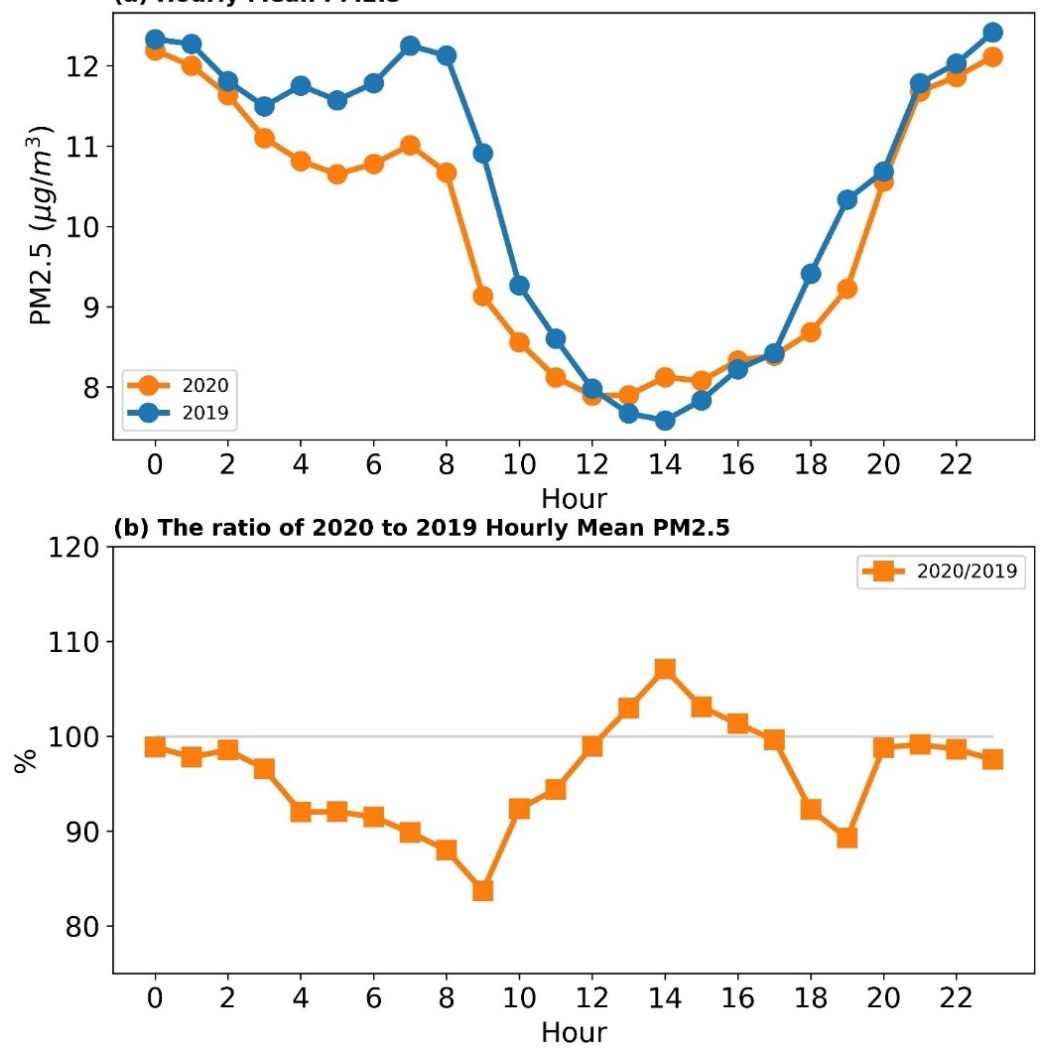

Fig. 6. Same as Fig. 5 but for Particulate Matter $2.5\left(\mathrm{PM}_{2.5}\right)$ concentrations measured by two urban ambient stations, South DeKalb and United Avenue.

Some $\mathrm{PM}_{2.5}$ is primarily emitted directly from vehicles, which may be associated with the reduced traffic volumes due to the COVID-19 lockdowns. On the other hand, $\mathrm{PM}_{2.5}$ is also produced through complex reactions of gases (Kroll et al., 2020). In sum, the reduced traffic may cause the reduction of $\mathrm{PM}_{2.5}$, but more studies are needed to understand the non-linear chemistry behind the reductions.

\section{CONCLUSIONS}

We have utilized satellite and ground measurements, and reanalysis data in conjunction with traffic information to understand how $\mathrm{NO}_{2}$, a major air pollutant, responses to the decreased human activities in the Atlanta metropolitan area during the 2020 COVID-19 lockdown (March 14-April 30, 2020). Human activities, measured by traffic volume, in 2020 COVID-19 lockdown period has decreased $48.7 \%$ relevance to the analogous period of 2019 . Furthermore, the human activities in 2020 have reduced $40 \%-50 \%$ during peak hours (6:00-19:00), and 50\%-63\% during off-peak hours (20:00-5:00).

Air quality in the Atlanta area during COVID-19 lockdown period has improved slightly, although human activities in 2020 are only approximately half of 2019. Ground $\mathrm{NO}_{2}$ in 2020 has reduced $10.8 \%$ and $8.2 \%$ by NR and UA stations, respectively. The reductions of ground $\mathrm{NO}_{2}$ indicate strong temporal variation in NR and UA stations. Tropospheric $\mathrm{NO}_{2}$ columns are observed $28.1 \%$ reductions by TROPOMI over the Atlanta area in 2020 COVID-19 lockdown period, compared to the analogous period of 2019. TROPOMI observations have indicated that tropospheric $\mathrm{NO}_{2}$ columns have decreased $\sim 23 \%$ and $\sim 21 \%$ over NR and UA stations, respectively, while collocated ground $\mathrm{NO}_{2}$ has increased $\sim 20 \%$ by the NR station and decreased $\sim 10 \%$ by the UA station on the overpass time of TROPOMI. Some factors may cause the disagreement on $\mathrm{NO}_{2}$ changes between ground and satellite observations. First, tropospheric $\mathrm{NO}_{2}$ columns measured by TROPOMI and ground $\mathrm{NO}_{2}$ concentrations measured ground stations are not necessarily the same, although they are highly correlated in the afternoon (Cersosimo et al., 2020; Demetillo et al., 2020). The 
decreased ground $\mathrm{NO}_{x}$ emission may cause different percentage changes in tropospheric $\mathrm{NO}_{2}$ columns and ground $\mathrm{NO}_{2}$ concentrations. Second, meteorological conditions may have different impacts on TROPMI and ground measurements. Third, TROPOMI may underestimate tropospheric $\mathrm{NO}_{2}$ due to uncertainties from air mass factors (Griffin et al., 2019). Forth, the uncertainties of chemiluminescence $\mathrm{NO}_{2}$ measurement may also contribute to this disagreement as these uncertainties reach maximum in the early afternoon and minimum in the morning (Dunlea et al., 2007; Lamsal et al., 2015). Consequently, studies using satellite and ground $\mathrm{NO}_{2}$ measurements should take these factors into account.

Ground ozone and $\mathrm{PM}_{2.5}$ both have decreased over the Atlanta area during the 2020 COVID-19 lockdowns. Ground ozone in 2020 has decreased $15.7 \%$ relevance to 2019 . The Atlanta area is $\mathrm{NO}_{x}$-controlled for ozone photochemistry due to the local $\mathrm{NO}_{\mathrm{x}}$ emission control (Jin et al., 2020; McDonald et al., 2018; Wolff et al., 2013). In 2020, the slightly increased HCHO concentrations over the southeast U.S. due to the warmer temperature made the Atlanta area a more $\mathrm{NO}_{\mathrm{x}}$-controlled scenario for ozone photochemistry.

$\mathrm{PM}_{2.5}$ in the 2020 COVID-19 period has decreased $\sim 5 \%$ relevance to the analogous period of 2019. Hourly $\mathrm{PM}_{2.5}$ concentrations in 2020 are slightly lower than 2019 in most time, but up to $\sim 8 \%$ higher during 13:00-16:00. The reduced traffic may cause the slight decrease of ground $\mathrm{PM}_{2.5}$, but further studies are needed to understand the non-linear chemistry of $\mathrm{PM}_{2.5}$.

Meteorological conditions have also contributed to the improvement of air quality over the Atlanta area in 2020 COVID-19 period. Higher wind speed and precipitations in 2020 are favorable for better air quality (Goldberg et al., 2020).

We conclude that air quality has improved slightly in the Atlanta area during 2020 COVID-19 lockdown (March 14-April 20, 2020) compared to the same period in 2019, although human activities has reduced $\sim 50 \%$. This slight improvement is primarily caused by reduced human activities induced by COVID-19 lockdowns. Meteorological conditions have also contributed to this improvement of air quality. Due to the complex chemistry, further studies are needed to quantitatively understand the impacts of reduced vehicle emissions on atmospheric chemistry as consequences of the COVID-19 pandemic.

\section{ACKNOWLEDGEMENT}

We acknowledge the TROPOMI science team for TROPOMI level 2 data, Georgia Department of Natural Resources for ground air quality data, and Georgia Department of Transportation for traffic data. R. Ponder acknowledges the support from the Center of Excellence for Minority Women in STEM's Department of Defense Research Scholars Program. We also thank DeAnna Oser of Georgia Department of Natural Resources for her valuable comments.

\section{FUNDING}

This research did not receive any specific grant from funding agencies in the public, commercial, or not-for-profit sectors.

\section{REFERENCES}

Atlanta Regional Commision (2020). Georgia Commute Options 2019 Regional Commuter Survey. Bauwens, M., Compernolle, S., Stavrakou, T., Müller, J.F., Gent, J. van, Eskes, H., Levelt, P.F., van $\operatorname{der}$ A., R., Veefkind, J.P., Vlietinck, J., Yu, H., Zehner, C. (2020). Impact of coronavirus outbreak on $\mathrm{NO}_{2}$ pollution assessed using TROPOMI and OMI observations. Geophys. Res. Lett. 47, e2020GL087978. https://doi.org/10.1029/2020GL087978

Bekbulat, B., Apte, J.S., Millet, D.B., Robinson, A.L., Wells, K.C., Presto, A.A., Marshall, J.D. (2021). Changes in criteria air pollution levels in the US before, during, and after Covid-19 stay-athome orders: Evidence from regulatory monitors. Sci. Total Environ. 769, 144693. https://doi.org/10.1016/j.scitotenv.2020.144693

Boersma, K.F., Eskes, H.J., Richter, A., De Smedt, I., Lorente, A., Beirle, S., Van Geffen, J.H.G.M., 
Zara, M., Peters, E., Van Roozendael, M., Wagner, T., Maasakkers, J.D., Van Der A, R.J., Nightingale, J., De Rudder, A., Irie, H., Pinardi, G., Lambert, J.C., Compernolle, S.C. (2018). Improving algorithms and uncertainty estimates for satellite $\mathrm{NO}_{2}$ retrievals: Results from the quality assurance for the essential climate variables (QA4ECV) project. Atmos. Meas. Tech. 11, 6651-6678. https://doi.org/10.5194/amt-11-6651-2018

Cersosimo, A., Serio, C., Masiello, G. (2020). TROPOMI NO 2 tropospheric column data: Regridding to $1 \mathrm{~km}$ grid-resolution and assessment of their consistency with in situ surface observations. Remote Sens. 12, 2212. https://doi.org/10.3390/rs12142212

Chen, L.W.A., Chien, L.C., Li, Y., Lin, G. (2020). Nonuniform impacts of COVID-19 lockdown on air quality over the United States. Sci. Total Environ. 745, 141105. https://doi.org/10.1016/j.scitot env.2020.141105

Demetillo, M.A.G., Navarro, A., Knowles, K.K., Fields, K.P., Geddes, J.A., Nowlan, C.R., Janz, S.J., Judd, L.M., Al-Saadi, J., Sun, K., McDonald, B.C., Diskin, G.S., Pusede, S.E. (2020). Observing nitrogen dioxide air pollution inequality using high-spatial-resolution remote sensing measurements in Houston, Texas. Environ. Sci. Technol. 54, 16, 9882-9895. https://doi.org/10.1021/acs.est.0c01864

Diem, J.E. (2009). Atmospheric characteristics conducive to high-ozone days in the Atlanta metropolitan area. Atmos. Environ. 43, 3902-3909. https://doi.org/10.1016/j.atmosenv.2009. 04.050

Dunlea, E.J., Herndon, S.C., Nelson, D.D., Volkamer, R.M., San Martini, F., Sheehy, P.M., Zahniser, M.S., Shorter, J.H., Wormhoudt, J.C., Lamb, B.K., Allwine, E.J., Gaffney, J.S., Marley, N.A., Grutter, M., Marquez, C., Blanco, S., Cardenas, B., Retama, A., Ramos Villegas, C.R., Kolb, C.E., et al. (2007). Evaluation of nitrogen dioxide chemiluminescence monitors in a polluted urban environment. Atmos. Chem. Phys. 7, 2691-2704. https://doi.org/10.5194/acp-7-2691-2007

Eskes, H.J., Eichmann, K.U. (2019). S5P Mission Performance Centre Nitrogen Dioxide [L2_NO2__ Readme. https://doi.org/10.5270/S5P-s4ljg54

Gelaro, R., McCarty, W., Suárez, M.J., Todling, R., Molod, A., Takacs, L., Randles, C.A., Darmenov, A., Bosilovich, M.G., Reichle, R., Wargan, K., Coy, L., Cullather, R., Draper, C., Akella, S., Buchard, V., Conaty, A., Silva, A.M. da, Gu, W., Kim, G.K., et al. (2017). The Modern-Era Retrospective analysis for Research and Applications, version 2 (MERRA-2). J. Clim. 30, 5419-5454. https://doi.org/10.1175/jcli-d-16-0758.1

Georgia Department of Natural Resources (2019). 2019 Air Quality Report, Georgia Department of Natural Resrouces. Atlanta, GA.

Georgia Department of Natural Resources (2020). 2020 Ambient Air Monitoring Plan. Atlanta, GA. Gkatzelis, G.I., Gilman, J.B., Brown, S.S., Eskes, H., Gomes, A.R., Lange, A.C., McDonald, B.C., Peischl, J., Petzold, A., Thompson, C.R., Kiendler-Scharr, A. (2021). The global impacts of COVID19 lockdowns on urban air pollutionA critical review and recommendations. Elem. Sci. Anth. 9, 00176. https://doi.org/10.1525/ELEMENTA.2021.00176

Goldberg, D.L., Anenberg, S.C., Griffin, D., McLinden, C.A., Lu, Z., Streets, D.G. (2020). Disentangling the impact of the COVID-19 lockdowns on urban $\mathrm{NO}_{2}$ from natural variability. Geophys. Res. Lett. 47, e2020GL089269. https://doi.org/10.1029/2020GL089269

Griffin, D., Zhao, X., McLinden, C.A., Boersma, F., Bourassa, A., Dammers, E., Degenstein, D., Eskes, H., Fehr, L., Fioletov, V., Hayden, K., Kharol, S.K., Li, S.M., Makar, P., Martin, R.V., Mihele, C., Mittermeier, R.L., Krotkov, N., Sneep, M., Lamsal, L.N., et al. (2019). High-Resolution mapping of nitrogen dioxide with TROPOMI: First results and validation over the Canadian oil sands. Geophys. Res. Lett. 46, 1049-1060. https://doi.org/10.1029/2018GL081095

Henneman, L.R.F., Holmes, H.A., Mulholland, J.A., Russell, A.G. (2015). Meteorological detrending of primary and secondary pollutant concentrations: Method application and evaluation using long-term (2000-2012) data in Atlanta. Atmos. Environ. 119, 201-210. https://doi.org/10.1016/ j.atmosenv.2015.08.007

Henneman, L.R., Chang, H.H., Liao, K.J., Lavoué, D., Mulholland, J.A., Russell, A.G. (2017). Accountability assessment of regulatory impacts on ozone and $\mathrm{PM}_{2.5}$ concentrations using statistical and deterministic pollutant sensitivities. Air Qual Atmos Health 10, 695-711. https://doi.org/10.1007/s11869-017-0463-2

Huang, G., Sun, K. (2020). Non-negligible impacts of clean air regulations on the reduction of tropospheric $\mathrm{NO}_{2}$ over East China during the COVID-19 pandemic observed by OMI and TROPOMI. Sci. Total Environ. 745, 141023. https://doi.org/10.1016/j.scitotenv.2020.141023 
Jin, X., Jin, X., Fiore, A., Fiore, A., Boersma, K.F., Boersma, K.F., De Smedt, I., Valin, L. (2020). Inferring changes in summertime surface ozone-NO $\mathrm{NO}_{\mathrm{x}} \mathrm{VOC}$ chemistry over U.S. urban areas from two decades of satellite and ground-based observations. Environ. Sci. Technol. 54, 65186529. https://doi.org/10.1021/acs.est.9b07785

Kerr, G.H., Goldberg, D.L., Anenberg, S. (2021). COVID-19 pandemic reveals persistent disparities in nitrogen dioxide pollution. ESSOAr https://doi.org/10.1002/ESSOAR.10504561.3

Koo, J.H., Kim, Jhoon, Lee, Y.G., Park, S.S., Lee, S., Chong, H., Cho, Y., Kim, Jaemin, Choi, K., Lee, T. (2020). The implication of the air quality pattern in South Korea after the COVID-19 outbreak. Sci. Rep. 10, 22462. https://doi.org/10.1038/s41598-020-80429-4

Kroll, J.H., Heald, C.L., Cappa, C.D., Farmer, D.K., Fry, J.L., Murphy, J.G., Steiner, A.L. (2020). The complex chemical effects of COVID-19 shutdowns on air quality. Nat. Chem. 12, 777-779. https://doi.org/10.1038/s41557-020-0535-z

Lamsal, L.N., Duncan, B.N., Yoshida, Y., Krotkov, N.A., Pickering, K.E., Streets, D.G., Lu, Z. (2015). U.S. $\mathrm{NO}_{2}$ trends (2005-2013): EPA Air Quality System (AQS) data versus improved observations from the Ozone Monitoring Instrument (OMI). Atmos. Environ. 110, 130-143. https://doi.org/ 10.1016/j.atmosenv.2015.03.055

Lamsal, L.N., Martin, R. V, van Donkelaar, A., Steinbacher, M., Celarier, E.A., Bucsela, E., Dunlea, E.J., Pinto, J.P. (2008). Ground-level nitrogen dioxide concentrations inferred from the satellite-borne Ozone Monitoring Instrument. J. Geophys. Res. 113, 16308. https://doi.org/10. 1029/2007JD009235

Lamsal, L.N., Martin, R. V., Parrish, D.D., Krotkov, N.A. (2013). Scaling relationship for $\mathrm{NO}_{2}$ pollution and urban population size: A satellite perspective. Environ. Sci. Technol. 47, 78557861. https://doi.org/10.1021/es400744g

Le, T., Wang, Y., Liu, L., Yang, J., Yung, Y.L., Li, G., Seinfeld, J.H. (2020). Unexpected air pollution with marked emission reductions during the COVID-19 outbreak in China. Science 369, 702706. https://doi.org/10.1126/science.abb7431

Liu, F., Page, A., Strode, S.A., Yoshida, Y., Choi, S., Zheng, B., Lamsal, L.N., Li, C., Krotkov, N.A., Eskes, H., A, R. van der, Veefkind, P., Levelt, P.F., Hauser, O.P., Joiner, J. (2020). Abrupt decline in tropospheric nitrogen dioxide over China after the outbreak of COVID-19. Sci. Adv. 6, eabc2992. https://doi.org/10.1126/sciadv.abc2992

Lorente, A., Folkert Boersma, K., Yu, H., Dörner, S., Hilboll, A., Richter, A., Liu, M., Lamsal, L.N., Barkley, M., De Smedt, I., Van Roozendael, M., Wang, Y., Wagner, T., Beirle, S., Lin, J.T., Krotkov, N., Stammes, P., Wang, P., Eskes, H.J., Krol, M. (2017). Structural uncertainty in air mass factor calculation for $\mathrm{NO}_{2}$ and $\mathrm{HCHO}$ satellite retrievals. Atmos. Meas. Tech. 10, 759-782. https://doi.org/10.5194/amt-10-759-2017

McDonald, B.C., McKeen, S.A., Cui, Y.Y., Ahmadov, R., Kim, S.W., Frost, G.J., Pollack, I.B., Peischl, J., Ryerson, T.B., Holloway, J.S., Graus, M., Warneke, C., Gilman, J.B., De Gouw, J.A., Kaiser, J., Keutsch, F.N., Hanisco, T.F., Wolfe, G.M., Trainer, M. (2018). Modeling ozone in the Eastern U.S. using a fuel-based mobile source emissions inventory. Environ. Sci. Technol. 52, 73607370. https://doi.org/10.1021/acs.est.8b00778

Morales-Solís, K., Ahumada, H., Rojas, J.P., Urdanivia, F.R., Catalán, F., Claramunt, T., Toro, R.A., Manzano, C.A., Leiva-Guzmán, M.A. (2021). The effect of COVID-19 lockdowns on the air pollution of urban areas of central and southern Chile. Aerosol Air Qual. Res. 21, 200677. https://doi.org/10.4209/aaqr.200677

Naeger, A.R., Murphy, K. (2020). Impact of COVID-19 containment measures on air pollution in California. Aerosol Air Qual. Res. 20, 2025-2034. https://doi.org/10.4209/aaqr.2020.05.0227

Oo, T.K., Arunrat, N., Kongsurakan, P., Sereenonchai, S., Wang, C. (2021). Nitrogen dioxide $\left(\mathrm{NO}_{2}\right)$ level changes during the control of COVID-19 pandemic in Thailand. Aerosol Air Qual. Res. 21, 200440. https://doi.org/10.4209/aaqr.200440

Park, Y.M., Kwan, M.P. (2020). Understanding racial disparities in exposure to traffic-related air pollution: Considering the spatiotemporal dynamics of population distribution. Int. J. Environ. Res. Public Health 17, 908. https://doi.org/10.3390/ijerph17030908

Represa, N.S., Della Ceca, L.S., Abril, G., García Ferreyra, M.F., Scavuzzo, C.M. (2021). Atmospheric pollutants assessment during the covid-19 lockdown using remote sensing and ground-based measurements in buenos aires, argentina. Aerosol Air Qual. Res. 21, 200486. https://doi.org/1 0.4209/aaqr.2020.07.0486 
Richmond-Bryant, J., Chris Owen, R., Graham, S., Snyder, M., McDow, S., Oakes, M., Kimbrough, S. (2017). Estimation of on-road $\mathrm{NO}_{2}$ concentrations, $\mathrm{NO}_{2} / \mathrm{NO}_{x}$ ratios, and related roadway gradients from near-road monitoring data. Air Qual. Atmos. Health 10, 611-625. https://doi.org/10.1007/s11869-016-0455-7

Rissman, J., Arunachalam, S., BenDor, T., West, J.J. (2013). Equity and health impacts of aircraft emissions at the Hartsfield-Jackson Atlanta International Airport. Landsc. Urban Plan. 120, 234-247. https://doi.org/10.1016/j.landurbplan.2013.07.010

Schiermeier, Q. (2020). Why pollution is plummeting in some cities - but not others. Nature 580, 313-313. https://doi.org/10.1038/d41586-020-01049-6

Seinfeld, J.H., Pandis, S.N. (2016). Atmospheric Chemistry and Physics: From Air Pollution to Climate Change, 3rd Edition, Wiley. John Wiley \& Sons.

Servadio, J.L., Lawal, A.S., Davis, T., Bates, J., Russell, A.G., Ramaswami, A., Convertino, M., Botchwey, N. (2019). Demographic inequities in health outcomes and air pollution exposure in the Atlanta area and its relationship to urban infrastructure. J. Urban Health 96, 219-234. https://doi.org/10.1007/s11524-018-0318-7

Shi, X., Brasseur, G.P. (2020). The response in air quality to the reduction of Chinese economic activities during the COVID-19 outbreak. Geophys. Res. Lett. 47, e2020GL088070. https://doi.org/10.1029/2020GL088070

Sun, K., Zhu, L., Cady-Pereira, K., Chan Miller, C., Chance, K., Clarisse, L., Coheur, P.F.F., González Abad, G., Huang, G., Liu, X., Van Damme, M., Yang, K., Zondlo, M. (2018). A physics-based approach to oversample multi-satellite, multispecies observations to a common grid. Atmos. Meas. Tech. 11, 6679-6701. https://doi.org/10.5194/amt-11-6679-2018

Sun, W., Zhu, L., De Smedt, I., Bai, B., Pu, D., Chen, Y., Shu, L., Wang, D., Fu, T., Wang, X., Yang, X. (2021). Global significant changes in formaldehyde (HCHO) columns observed from space at the early stage of the COVID-19 pandemic. Geophys. Res. Lett. 48, e2020GL091265. https://doi.org/10.1029/2020GL091265

The State of Georgia (2020a). Declaration of Public Health State of Emergency.

The State of Georgia (2020b). Excecutive Order to Ensure a Safe \& Healthy Georgia.

Van Geffen, J.H.G.M., Boersma, K.F., Van Roozendael, M., Hendrick, F., Mahieu, E., De Smedt, I., Sneep, M., Veefkind, J.P. (2015). Improved spectral fitting of nitrogen dioxide from OMI in the 405-465 nm window. Atmos. Meas. Tech. 8, 1685-1699. https://doi.org/10.5194/amt-8-16852015

Veefkind, J.P., Aben, I., McMullan, K., Förster, H., de Vries, J., Otter, G., Claas, J., Eskes, H.J., de Haan, J.F., Kleipool, Q., van Weele, M., Hasekamp, O., Hoogeveen, R., Landgraf, J., Snel, R., Tol, P., Ingmann, P., Voors, R., Kruizinga, B., Vink, R., et al. (2012). TROPOMI on the ESA Sentinel-5 Precursor: A GMES mission for global observations of the atmospheric composition for climate, air quality and ozone layer applications. Remote Sens. Environ. 120, 70-83. https://doi.org/10. 1016/j.rse.2011.09.027

Venkatram, A., Snyder, M., Isakov, V., Kimbrough, S. (2013). Impact of wind direction on nearroad pollutant concentrations. Atmos. Environ. 80, 248-258. https://doi.org/10.1016/j.atmo senv.2013.07.073

Wolff, G.T., Kahlbaum, D.F., Heuss, J.M. (2013). The vanishing ozone weekday/weekend effect. J. Air Waste Manage. Assoc. 63, 292-299. https://doi.org/10.1080/10962247.2012.749312 